\title{
CONCWEB: HYBRID LEARNING TOOL FOR REINFORCED CONCRETE DESIGN
}

\author{
CONCWEB: UMA FERRAMENTA HÍBRIDA DE APRENDIZAGEM PARA PROJETO DE \\ CONCRETO ARMADO
}

\section{CONCWEB: UNA HERRAMIENTA DE APRENDIZAJE HÍBRIDO PARA PROYECTO DE CONCRETO REFORZADO}

\author{
Gláucia Nolasco de Almeida Mello ${ }^{1}$ \\ Elizabeth Vieira Maia ${ }^{2}$ \\ José Márcio Fonseca Calixto ${ }^{3}$
}

\begin{abstract}
The use of web has become an attractive option for the development of learning environments due to the high interactive interfaces which computers have throughout their multimedia resources - graphic, videos, animation and simulation. In this scenario, this paper presents an analysis of the influence of ConcWeb online virtual environment on the learning process for reinforced concrete design. The collected data consisted of student's exams from which a longitudinal study was used to obtain the results. All measurements were obtained during the course of one semester and were adjusted to hierarchical linear models in order to describe the students' learning trajectories. The final results show a positive influence of ConcWeb in the students' learning process. Since the students are stimulated to access the virtual environment, ConcWeb is a great tool to assist them in the process of learning reinforced concrete design as well as to assist lectures teach this subject to engineering majors.
\end{abstract}

KEYWORDS: Engineering education. Simulation. E-learning. Longitudinal analysis.

RESUMO: O uso da web tem se tornado uma alternativa atrativa para o desenvolvimento de ambientes virtuais devidas às possibilidade de implementação de interfaces interativas com a utilização de recursos multimídia, tais como: gráfico, vídeo, animação e simulação. Com base neste cenário, este artigo apresenta uma análise da influência do ambiente virtual ConcWeb na processo de aprendizagem da disciplina de projeto de estruturas de concreto armado. Os dados foram coletados das avaliações dos alunos a partir dos quais um estudo longitudinal foi empregado para a obtenção dos resultados. Todas as medições foram realizadas durante o semestre letivo e foram ajustadas para um modelo linear hierárquico para que fosse possível descrever a trajetória dos alunos. Os resultados finais mostram uma influência positiva do ConcWeb no desempenho dos alunos. Quando estimulados a utilizar o ambiente virtual ConcWeb, este pode se tronar uma grande ferramenta de auxílio no processo de aprendizagem de projeto de estruturas de concreto armado, além de atuar como suporte às aulas presenciais.

\footnotetext{
${ }^{1}$ Doutora em Engenharia de Estruturas, Universidade Federal de Minas Gerais - UFMG, Belo Horizonte, MG Brasil. Professora adjunta da Pontifícia Universidade Católica de Minas Gerais, PUCMG, Belo Horizonte, MG - Brail. E-mail: gnamello@pucminas.br.

2 Doutora em Educação pela Universidade Federal de Minas Gerais - UFMG, Belo Horizonte, MG - Brasil. Professora adjunta do Departamento de Engenharia de Estruturas, UFMG, Belo Horizonte, MG - Brasil. E-mail: bethmaia@dees.ufmg.br.

3 Doutor em Engenharia Civil pela Universidade do Texas, Estados Unidos. Professor associado do Departamento de Engenharia de Estruturas, Universidade Federal de Minas Gerais, UFMG, Belo Horizonte, MG - Brasil. E-mail: calixto@ dees.ufmg.br.

Recebido em: 06/07/2015 - Aprovado em: 13/02/2015.
} 
PALAVRAS-CHAVE: Educação em Engenharia. Simulação. Ambiente web de aprendizagem. Análise longitudinal.

RESUMEN: El uso de la web se ha convertido en una alternativa atractiva para el desarrollo de sitios de aprendizaje debido a la posibilidad de implementar interfaces interactivas con el uso de los recursos multimedia, como gráficos, video, animación y simulación. Este trabajo presenta un análisis de la influencia del sitio virtual ConcWeb en el proceso de aprendizaje de diseño de estructuras de hormigón armado. Los datos fueron obtenidos de las evaluaciones de los estudiantes y se utilizó un estudio longitudinal para obtener los resultados. Todas las mediciones se llevarán a cabo durante el semestre y se han ajustado a un modelo lineal jerárquico para la descripción de la trayectoria de los estudiantes. El sitio virtual ConcWeb tuvo un impacto positivo en el desempeño del estudiante. Cuando alentados a utilizar el sitio virtual ConcWeb, esto puede tronar una gran herramienta de apoyo en el proceso de aprendizaje de diseño de hormigón armado, además de actuar como apoyo a las clases regulares.

PALABRAS CLAVE: Enseñanza de ingeniería, simulación, sitios de aprendizaje, estudio longitudinal.

\section{INTRODUCTION}

Despite the dominance of traditional classroom teaching in structural engineering in Brazil, professors have also been using computer systems in processes that involve a lot of calculations. These systems are general business oriented software for professionals' purposes: SAP2000® (2015), CYPECAD ${ }^{\circledR}$ (Multiplus, 2015), and TQS ${ }^{\circledR}$ (2015). It is important to distinguish between business and instructional software because pedagogical aspects must be considered in the development of the latter.

Furthermore, it has became evident for professors the problems that interfere with students' performance such as lack of motivation, pupils who do have not enough knowledge about basic concepts necessary to understand behavior of structures, and students' difficulty to visualize the design processes for concrete, steel and wood elements (Molyneaux et al, 2007).

Shepherdson (2001) shows that deficiencies in the business oriented systems have been detected by construction sector companies and industries as well as:

- Students have difficulty analyzing and understanding the results presented by professional software developed for structural engineering;

- Students have difficulty recognizing wrong results presented by software;

- Lack of ability in visualizing the structural behavior based on the analysis of result report provided by professional software and in presenting the solution for the problem.

At the same time, the traditional process of teaching and learning has been improved by technology, and one of the most popular resources in this process is the use of digital online contents. Nowadays there is significant enthusiasm for online courses to help the students (Online Learning Consortium, 2015; Pontydysgu, 2015; Swedish National Agency for Higher Education, 2008; ABED, 2015; Lauwton et al, 2012). Several factors contribute to it: access to knowledge anywhere and anytime (Takahashi, 2000), the rapid growth of digital technology resources, and the existence of a new generation named "native digitals" (Bennett \& Maton, 2010). This is not different for engineering majors: many universities worldwide

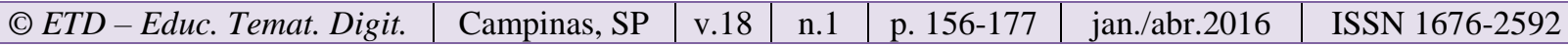


provide online contents (MIT, 2015; PUC-Rio, 2015), and sometimes even full online courses that are totally free by MOOC (Massive Open Online Courses) websites (edX®, 2015; Coursera ${ }^{\circledR}, 2015$; Veduca $\left.{ }^{\circledR}, 2015\right)$.

Drysdale et al. (2013) identified and analyzed over 200 thesis and dissertations written between 1999 and 2011 in the domain of blended/hybrid learning in K-12 and higher education. The study does not specify the areas of knowledge. A total of 106 manuscripts were identified in the investigation from which $51.5 \%$ was related to the learner outcomes (performance outcomes, student satisfaction, engagement, effectiveness, motivation and effort, independence in learning, retention rates) and, 33,7\% of them was about success rates and transformation of student learning in hybrid instructional delivery. Finally they emphasize that there is not a theoretical frameworks that explore the potential and limitations of blended learning to guide teachers on how to use it effectively.

In their literature review, Güzer e Caner (2014) observed that blended/hybrid learning was used on a variety of schools and participants ranging from postgraduate students to middle school students; from nursing to English courses and from training programs to high level courses for military personnel. The results showed that blended learning was perceived by learners as useful, enjoyable, supportive, flexible and motivator.

Although reasonable amount of research about hybrid learning in higher education can be found in the literature, no study, to our knowledge, has been conducted about the subject in engineering education, more specifically in structural engineering education.

In this scenario, the overall motivation for this research is to obtain evidence that online activities in civil engineering contributes to improving students' performance. In achieving this goal, reinforced concrete design was the selected course for the evaluation. A website named ConcWeb (http://concweb.lcc.ufmg.br/) was designed and developed. It has many tools and resources - text, animations, simulations and videos - to help students anytime and anywhere. The students had access to the website during three quarters of a semester and could work on activities suggested by the professors. The students' navigation through ConcWeb was monitored by the system from which a data file was generated containing information regarding the dates, the duration and the contents accessed by all users.

\section{METHODS}

\section{ConcWeb: Virtual Learning Environment}

Figure 1 shows ConcWeb diagram. It is composed of hypertext, multimedia resources and simulators that enable learners to explore phenomenon by testing hypotheses through the control of variables and parameters. 


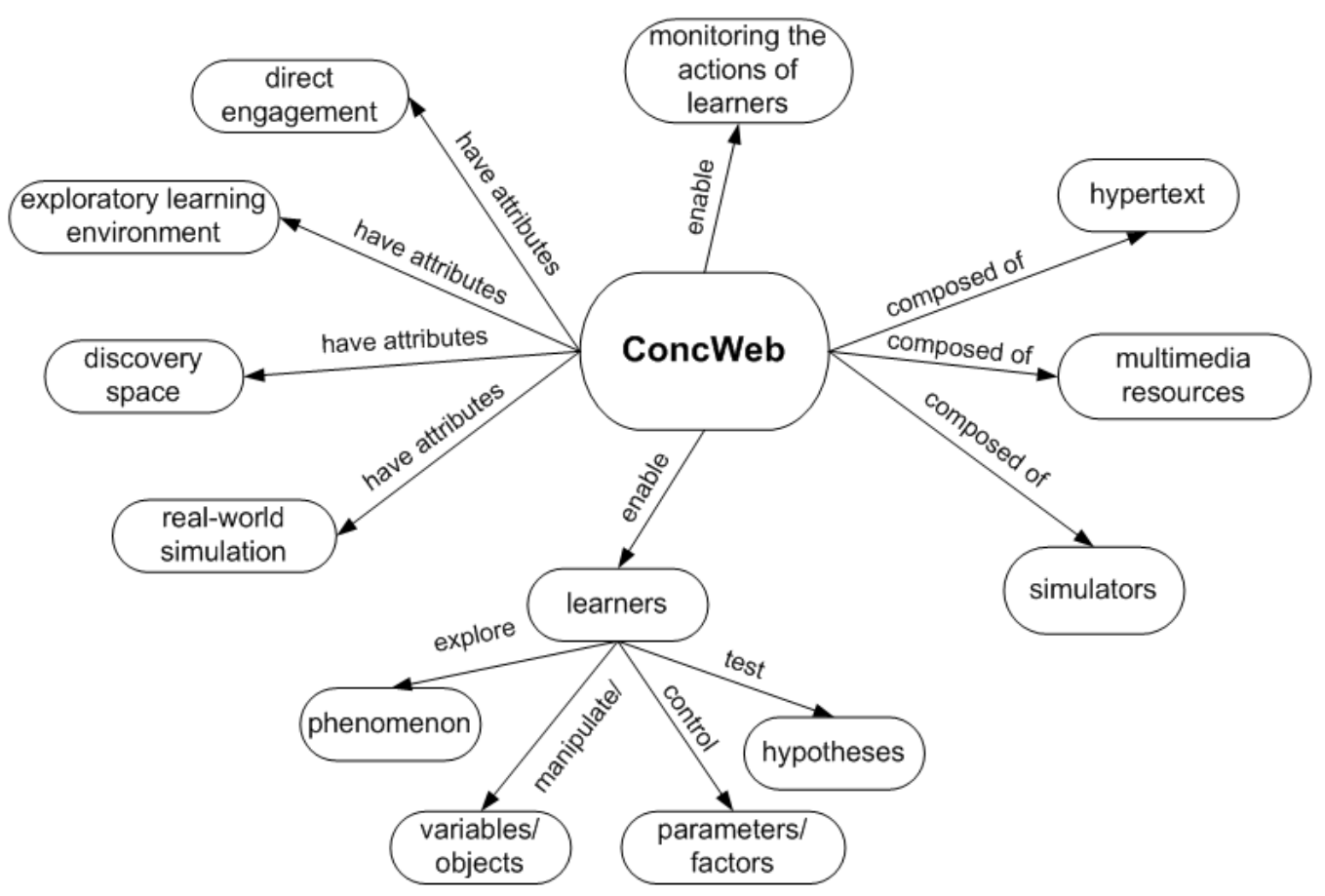

Figure 1 - ConcWeb diagram as cognitive tool.

For educational contents, it is important to consider some relevant aspects about the appearance and architecture, when planning the whole project; i.e., attract the attention of users and stimulate repeated access to the environment. Problems related to usability appear just after users leave the homepage and start surfing the website (Nielsen \& Loranger, 2007). Therefore, the website must be designed as simple as possible and should follow three "golden rules" (Pressman, 2007): (1) place the user in control; (2) reduce the user's memory load; (3) make the interface consistent. Shneiderman and Plaisant (2005) say that is more difficult to establish the interface pattern in accordance with all design criteria because of the exploratory nature of educational environments. These authors as well as Nielsen and Loranger (2007) point to some cares with interface design related to error messages, feedbacks, colors and information organization on the computer screen. Nielsen and Loranger (2007) also emphasize that there are two main design aspects to be considered: the artistic ideal and the engineering ideal in order to solve the client's problem. It is vital to pay attention to both aspects when a website is developed. Specifically for educational environments, the artistic attributes increase motivation but it is not enough to maintain the assiduousness and to guarantee the success of the learning process. In the end, the ConcWeb was designed following those suggestions.

ConcWeb also provides reinforced concrete design simulators. They are Java applets to enable the calculation of the reinforcement for rectangular cross-sections subjected to shear, simple bending and the combination of axial loads and bending on one axis. In this way, the overall solutions for a proposed problem can be verified, allowing students to understand better the design procedures for these types of member actions. Figure 2 presents the design of a $20 \times 60$ centimeter rectangular cross-section subjected to combined axial load and 
bending on one axis. After the inclusion of the necessary information (section dimensions, material properties, axial load and bending moment), the user then presses the EXECUTAR button to get the results. The necessary calculations as well as the final results are shown on the right side of the screen.

If the user wants the reinforcement detailing of the designed cross-section, he must provide the diameters for longitudinal and transversal reinforcing bars as well as the concrete cover. After that, one needs to press the VISUALIZAR RESULTADOS button. A three dimensional sketch of the rectangular cross-section is shown with the location of the reinforcing bars. The users are then able to move the sketch around and visualize it from different points of view. This feature provides an exploratory environment from which students are able to change cross-sections sizes, bending moment values, bar diameters and verify the consequences. Figure 3 shows the three dimensional sketch for the bar diameters and concrete cover presented at the bottom right hand side of the screen.

The ConcWeb was constructed using Joomla! ${ }^{\circledR}(2015)$. Although it is not necessarily focused on educational environments, Joomla! is adequate for the goals of this research. It provides functionality and integrated components to build online environments quickly and often, with little or no programming at all. It also provides many tools and resources needed in developing educational websites. Furthermore, it is compatible with system server used at UFMG Science Computational Laboratory (LCC, 2015).

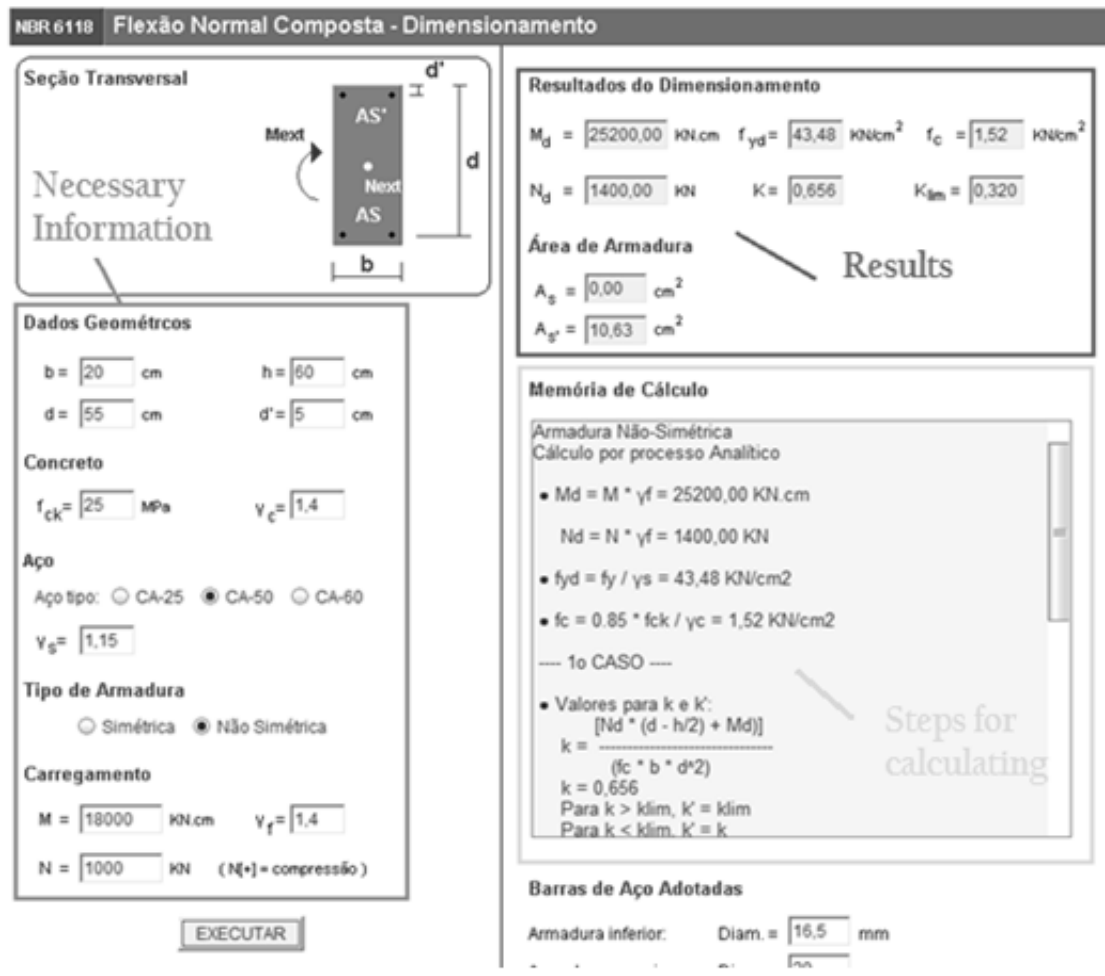

Figure 2 - ConcWeb simulator for normal bending composed.

Source: Personal archive. 


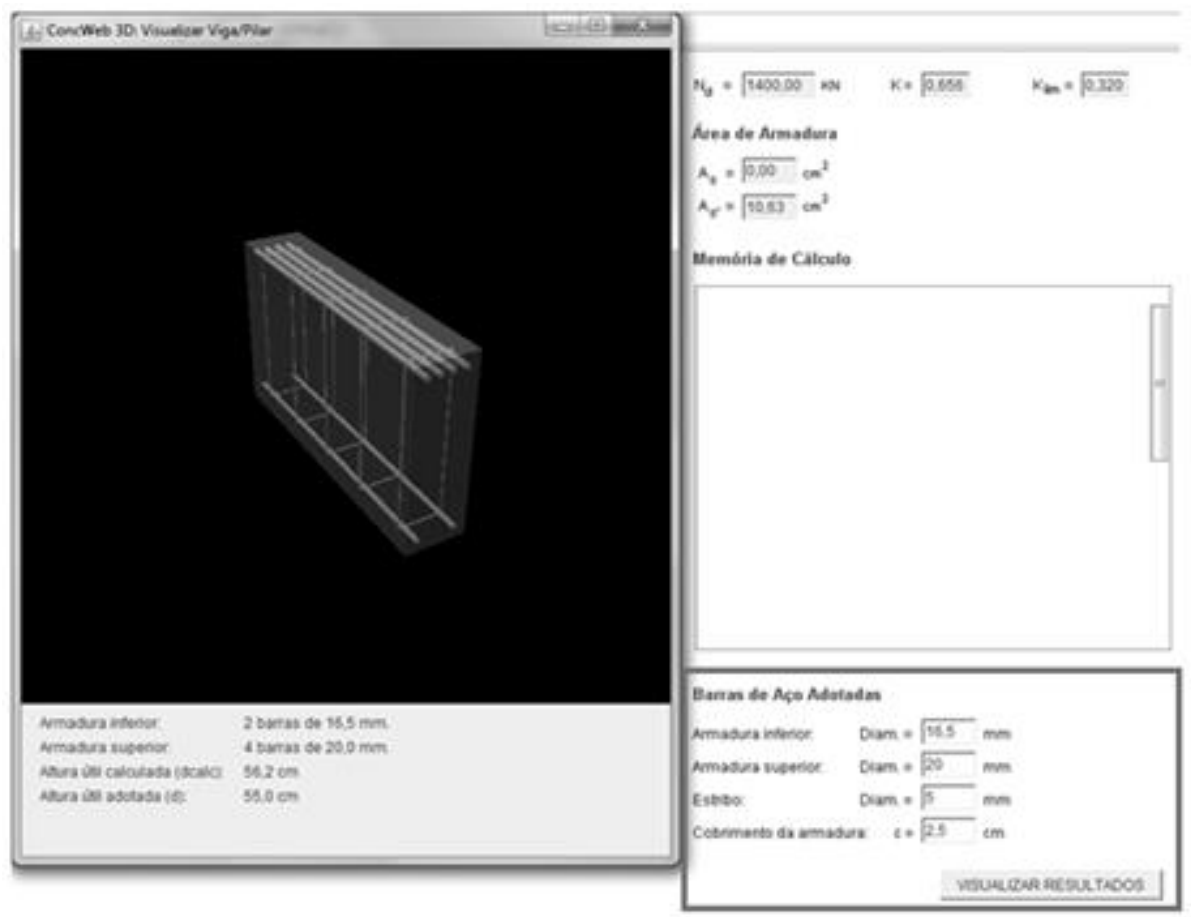

Figure 3 - Three dimensional reinforcement detailing sketch

Source: Personal archive.

\section{Participants}

Data of 145 civil engineering majors was analyzed. The control group consisted of 74 students who had no access to the ConcWeb virtual environment. The treatment group had 71 students. The collected data for both groups consisted of pupils' academic information provided by the registrar's office, homework evaluations, analysis of the solution for three identical classroom exams and responses to a questionnaire. For the treatment group, data also included information about the access to ConcWeb (dates, duration and contents) and answers to a specific questionnaire about the environment. A short description of the student profiles is shown in Table 1. Each group was composed of approximately $70 \%$ male and 30\% female students and most of the students were between 21 and 25 years of age.

\section{Statistical Methods}

To access the influence of ConcWeb website on learning reinforced concrete design more than one statistical model was applied to empirical data. While Rasch model is concerned with describing the probability of a student answering a question correctly (Mead, 2008), longitudinal studies describe how each person in the sample changes over time (Singer $\&$ Willet, 2003). Both of them are essential for this research and will be briefly described. 
Table 1 - Participants' description.

\begin{tabular}{|c|c|c|c|}
\hline Group & Charac & & Students $(\%)$ \\
\hline \multirow{14}{*}{ 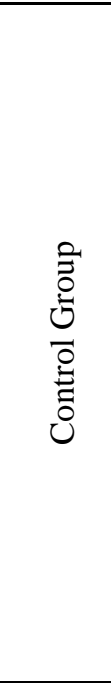 } & \multirow{4}{*}{ Age } & $21-25$ & 63 \\
\hline & & $26-30$ & 30 \\
\hline & & $31-35$ & 4 \\
\hline & & $>35$ & 3 \\
\hline & \multirow{2}{*}{ Gender } & Female & 30 \\
\hline & & Male & 70 \\
\hline & \multirow{2}{*}{ High school location } & Belo Horizonte & 46 \\
\hline & & Other & 54 \\
\hline & \multirow{2}{*}{ High school ownership } & State & 34 \\
\hline & & Private & 66 \\
\hline & \multirow{3}{*}{ Current semester at the university } & 7 & 21 \\
\hline & & 8 a 10 & 70 \\
\hline & & $>10$ & 9 \\
\hline & Students who worked* & & 11 \\
\hline \multirow{15}{*}{ 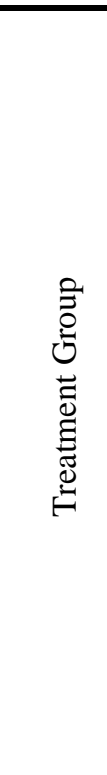 } & \multirow{4}{*}{ Age } & $21-25$ & 73 \\
\hline & & $26-30$ & 23 \\
\hline & & $31-35$ & 3 \\
\hline & & $>35$ & 1 \\
\hline & \multirow{2}{*}{ Gender } & Female & 30 \\
\hline & & Male & 70 \\
\hline & \multirow{2}{*}{ High school location } & Belo Horizonte & 39 \\
\hline & & Other & 61 \\
\hline & \multirow{2}{*}{ High school ownership } & State & 32 \\
\hline & & Private & 68 \\
\hline & \multirow{3}{*}{ Current semester at the university } & 7 & 37 \\
\hline & & 8 a 10 & 55 \\
\hline & & $>10$ & 8 \\
\hline & \multicolumn{2}{|l|}{ Students who worked* } & 23 \\
\hline & \multicolumn{2}{|l|}{$\begin{array}{l}\text { Students who } \quad \text { accessed } \\
\text { ConcWeb }\end{array}$} & 66 \\
\hline
\end{tabular}

*Student who works for structural engineering company as part-time trainee.

Source: The authors.

\section{Longitudinal studies}

Scientific research whose interest is evaluating the behavior of one or more variables over time is generally conducted by means of a longitudinal analysis. The main objective of this type of analysis is to provide evidence which can describe change patterns in persons or entities over time. Thus, the collected data must be performed through repeated measurements. Singer \& Willet (2003) suggest three methodological features for longitudinal studies: (1) three or more waves of data; (2) an outcome whose values change systematically over time; and (3) a sensitive measure for real time. An important aspect of longitudinal studies is data collection since it is a determining factor for the statistical method chosen for 
the analysis. The data can be collected over a period of time when the objects of study are observed or they can be obtained by historical registries. (Diggle et al., 2002).

A longitudinal study in the educational area aims at answering the following questions: (1) How does each person's performance change over time? (2) What differences can be predicted among people in their changes? The first question is descriptive and aims at characterizing each person's change pattern over time. Is individual change linear? Nonlinear? Is it consistent over time or does it fluctuates? The second question is relational and tries to examine the association between predictors and patterns of change (Singer \& Willet, 2003), (Diggle et al., 2002). So a longitudinal study is a two level process of analysis: the first one (known as level-1) aims at individual change over time; the second one describes each person's individual growth trajectory i.e., the way his or her outcome values rise and fall over time.

\section{Level-1: How does each person's performance change over time?}

The classical regression model assumes the existence of a straight line that represents how each person changes over time and every linearity deviation is related to a measurement error $e_{i j}$ (Singer e Willet, 2003), (Peugh, 2010):

$$
Y_{i j}=\left[\beta_{0 i}+\beta_{1 i} \cdot\left(\text { tempo }_{i j}\right)\right]+e_{i j}
$$

The $Y_{i j}$ is an explanatory dependent variable that represents how knowledge of a person $i$ change linearly over time $j ; \beta_{0 i}$ represents the intercept i.e., the initial stage of a person $i ; \beta_{l i}$ is the slope of the line which represents the rate of increase or decrease of a person performance over time $i$. The measurement error refers to individual effects of investigated subject and it is not noticed by the deterministic component of the model (Peugh, 2010). The usual assumption is to have a normal distribution with null mean and constant variance $\sigma_{\theta}^{2}$ between groups that are not correlated to each other. The normal distribution related to first level errors is expressed by the Equation 2 (Singer \& Willet, 2003), (Diggle et al., 2002), (Peugh, 2010):

$$
e_{i j} \approx N\left(0, \sigma_{e}^{2}\right)
$$

\section{Level-2: What differences can be predicted among people in their changes?}

To define the equation that represents the model at level-2, Singer e Willet (2003) suggest four important considerations: (1) the results of the equation must be the individual growth parameters, e. g. $\beta_{0 i}$ and $\beta_{1 i}$; (2) the level-2 model must be represented by two separate equations: one equation for each growth parameter at level-1, e.g. one for the intercept $\beta_{0 i}$ and another one for the slope; (3) each equation must be able to specify the relationship between the individual growth parameter and its predictor; (4) each model must share commons predictors of subjects which can modify their individual trajectories.

The last considerations lead to the Equations 3 and 4:

\begin{tabular}{l|l|l|l|l|l|l} 
(C) ETD - Educ. Temat. Digit. & Campinas, SP & v.18 & n.1 & p. 156-177 & jan./abr.2016 & ISSN 1676-2592
\end{tabular}




$$
\begin{aligned}
& \beta_{0 i}=\gamma_{00}+\gamma_{01} \cdot \text { preditor }_{i}+u_{0 i} \\
& \beta_{1 i}=\gamma_{10}+\gamma_{11} \cdot \text { preditor }_{i}+u_{1 i}
\end{aligned}
$$

The $\gamma_{00}, \gamma_{01}, \gamma_{10}$ and $\gamma_{11}$ are all regression parameters to fixed effects and $u_{0 i}$ and $u_{1 i}$ are residues. Thus, the composed multilevel model for change is represented by the Equation 5 (Singer \& Willet, 2003):

$$
\boldsymbol{Y}_{i j}=\left[\left(\gamma_{00}+\gamma_{01} \cdot \text { preditor }_{1 i}+u_{0 i}\right)+\left(\gamma_{10}+\gamma_{11} \cdot \text { preditor }_{2 i}+u_{1 i}\right) \cdot\left(\text { tempo }_{i j}\right)\right]+e_{i j}(5)
$$

\section{Rasch analysis}

There are many possibilities of measurements in the educational world and they are all very hard to obtain due to the fact that the attributes of interest are not easily seen as the objects of the physical world are (Mead, 2008). This means that competence cannot be visualized in the same way the house dimensions are measured. In educational environments, one can evaluate competence through observables variables, which indicate how the students respond to the academic tasks (Mead, 2008), (Wu \& Adams, 2007), (Ariffin et al, 2010). In this way a test based on a studied topic provides some information about student academic performance.

Rasch models have been used to construct the measure scale in the educational area (Ariffin et al, 2010), (Drouina et al, 2012), (Arsad et al. 2013). According to Mead (2008), Rasch developed a model analysis which converts ordinal data into interval measures with log-odds transformations i.e., logarithms of the probability of success. The basic idea of Rasch model is the greater a skill a person has, the higher will be his probability to get higher scores on all items, independent of the item difficulty level. On the other hand, the easier the item is, the higher the probability of everybody getting higher scores for it. When every item in the same scale is in accordance with that condition, it means that instrument is adequate to measure model and probability of higher skill individuals get higher scores is higher than persons who have lower skills.

The present study used a Rasch model for dichotomous data i.e. questions that are scored right or wrong, yes or no, agree or disagree, checked or not checked, present or absent, hit or miss, 1 or 0 .

The dichotomous data model is the simplest Rasch model and is expressed by Equation 6:

$$
P_{n i}=\frac{\exp \left(B_{n}-D_{i}\right)}{\left[1+\exp \left(B_{n}-D_{i}\right)\right]}
$$

Where $\boldsymbol{P}_{\boldsymbol{n} \text { i }}$ represents the probability of one person $\boldsymbol{n}$ who had ability $\boldsymbol{B}_{\boldsymbol{n}}$ to be successful with a measure item $\boldsymbol{i}$ that has a difficult degree $\boldsymbol{D}_{\boldsymbol{i}}$; both are measured through the 
same logarithmic scale - logits (unit that indicates a remarkable amount of knowledge that constitutes the clear difference between two people or two items, or one person at different times, such as before and after training (Linacre, 2012), (Mead, 2008). The main Rasch analysis objective is to examine how well the data fits the model. After extracting the data Rasch dimension, the residues must not be associated to each other, i.e.; the residues must be independent random variables. In this way, if data is well fitted to the Rasch model, then it is possible to consider the measurement only for one latent variable or construct (Linacre, 2012), (Wright \& Mok, 2004), (Mead, 2008).

\section{Procedure}

The experiment was carried out at Universidade Federal de Minas Gerais (UFMG, 2015) in Belo Horizonte, Brazil. The first part of the research was to apply three regular exams to control group and draw all data from the student exams results. The second one was to develop a ConcWeb virtual environment and choose the treatment group to have access to the website. As mentioned previously, the treatment group accessed all information and tools on ConcWeb and they were monitored during the time of use. The treatment group also took the same three exams as the control group did. Five sets of data were collected: three exams, practical tasks, questionnaire, academic information document and the latter only for the treatment group - statistical reports about website utilization.

\section{Data collected in the exams: dependent variable}

Unfortunately, we did not have a test for assessment of reinforced concrete knowledge; thus, we transformed the student exam answers into dichotomous items, according to a standard solution. The right answers were assigned value 1 ; otherwise value 0 was assigned to the item. For all items not completed value 0 was assigned as well.

Data collected in the practical tasks, questionnaire, academic information document and statistical reports: independent variables

As mentioned previously, predictor variables were required to describe the development learning via change trajectory. All predictors in this research are dichotomous variables that were taken by suitable set data transformations of practical tasks scores, academic student information, questionnaire answers and statistical reports data. Those predictors, briefly described below, represent the independent variables in the equation that describe the student trajectory of change for the reinforced concrete design course.

a) Predictors taken from student academic documentation: Gender is the first predictor taken from the student academic documentation: 1 was attributed for a male student and 0 for female one. It was named gender $N$. The second one is related to age group and indicates whether school life is regular or not. It was considered unusual, i.e., out of regular group age, for students to be two years behind. In Brazil, the regular age to get into university is eighteen years old. Civil Engineering Courses in Brazil takes five years. Thus, if a student graduates at the age of twenty-three years old, he is considered in the regular age group.

Since reinforced concrete design is a course of the 8th semester, all students 23 years old 
belonged to the regular age group. The variable predictor in this case was named ageN and it was attributed 1 for all students up to 23 years old; otherwise, it received 0 . Two predictors were created to represent characteristics about college students. The first one, named highSchoolLOC, received 1 when the student's high school was in the city of Belo Horizonte and 0, otherwise. The last one, named highSchoolOWN received value 1 when the high school was private own or 0 for state administrated high school.

b) College historical performance predictor: As shown in the Table 2, it is the indicator adopted by the university that measures the student performance during the semesters of the whole course. That parameter is called Global Performance (GP). Two predictors were obtained by the GP. The first one was taken by the academic performance semester global average named meanGSPN. In this case, the GSP's (Global Semester Performance) of all final semesters by students was considered. To be approved in any discipline the student must obtain a score of D or above which is equivalent to a minimum of $2.0 \mathrm{GP}$. The predictor meanGSPN received value 1 when GSP average was higher than 2.0, otherwise 0 was received. The second predictor meanGPStrWeighN, different from the first one, represents the weighted average of the structural engineering courses only. In the same way, value 1 was received when GSP average was higher than 2.0, otherwise a 0 was received.

c) Predictor to represent practical tasks: that indicator represents the influence of practical activities during the learning process. Its name is scorePTN and it was attributed the value of 1 when the student score of practical tasks was 6.0 or higher and 0 , otherwise. It should be emphasized that the treatment group could access the ConcWeb to solve these problems while the control group could not.

d) Predictors taken from the questionnaire related to students' professional life: Those indicators represent the influence of professional activities during the learning process. Two predictors were identified: workedSTRUCT and timeWORK. The first one was attributed the value of 1 when a student worked at a structural engineering company as a part time trainee and 0 , otherwise. The second one, timeWORK, is related to the duration of the job period in the structural engineering area. One was attributed to all students who worked at least one whole year. Otherwise, the attributed value was 0 . 
Table 2 - Relationship between scores and GP.

\begin{tabular}{ccc}
\hline Scores & & GP \\
\hline $90-100$ & A & 5 \\
\hline $80-89$ & B & 4 \\
\hline $70-79$ & C & 3 \\
\hline $60-69$ & D & 2 \\
\hline $40-59$ & E & 1 \\
\hline$<40$ & F & 0 \\
\hline
\end{tabular}

Source: the authors.

e) Predictors related to the ConcWeb access by each student: Just for the treatment group, two predictors were created related to the access to ConcWeb virtual environment. The first one, accessed was created based on statistical reports and represents the independent variable that indicates real access of student i.e., the access computed by the login and password. It received 1 when the login was presented in the reports, otherwise it received value 0 . The second one, named awareness, was based on the answer to the question about the access presented in questionnaire: "Have you ever accessed the ConcWeb?". When student answered YES, that predictor received 1, otherwise, it received 0 . That was considered because the students sometimes do practical tasks together. The predictor accessed is more reliable because it was verified in the reports in ConcWeb statistical tool and Google Analytics (2015) reports. The accessed predictor variable has a different value for the three data wave. In the first instance, i.e., first data wave, it was before the first exam so the treatment group of students did not had access the website so it was assigned 0 for each participant.

\section{Data Analyzes}

The dichotomous scores of all student exams were input data to the statistical package software MPlus ${ }^{\circledR}$ (Muthén \& Muthén, 2007). MPlus (MPlus, 2015) which is an appropriate software to perform exploratory factorial analyzes. The analysis was necessary because of the nature of reinforced concrete design course that involved many different contents. However, the obtained load factor map did not present a simple factor structure. Some items loaded in both factors were retained by the software and identified by the researchers:

1. Solid mechanics: it involves all items related to load analysis, geometrical sections dimensions, tension verification;

2. Reinforced concrete structures: it involves items related to design and detailing of reinforced concrete structures.

Thus the students' dichotomous scores were related to each factor: solid mechanics and reinforced concrete structures. In this way it is not possible to ensure that the difference between a pair of equidistant values are the same - interval measures (Singer e Willet, 2003); it is only possible to affirm which student has the higher or lower score (ordinal scale). Those scores are the raw data for the Rasch analyses, from which the interval scale for each factor 
of each exam is obtained. The specific software used to create to each measure scale was WINSTEPS® (2015).

The Rasch analysis results show three measure scales needed to describe the trajectory of change over time for students of reinforced concrete discipline in all identified domains (factors). The scale measure for solid mechanics domain was considered as a predictor variable because its topics are studied in others disciplines previously and are essential for understanding reinforced concrete design contents. The predictor for solid mechanics is called MechanicNLogit. It was transformed into dichotomous data and attributed the value 1, when the measure was higher than 0 logit; otherwise, it received 0 .

The SPSS ${ }^{\circledR}$ (2015) statistical software was used to perform the longitudinal analyses. It was considered the hierarchical model with two levels, as mentioned earlier.

\section{RESULTS}

In the Rasch context, the INFIT and OUTFIT statistics indicate the precision of data fitted to the model. The magnitude of these indexes is related to the existence of unexpected answers, i.e., wrong answers for the easiest items and right answers for the more difficult items. The more frequent is the unexpected mistake and success rate, the higher will be the INFIT and OUTFIT statistics (Linacre, 2012). Most INFIT and OUTFIT results are all within the expected value, approximately 1.0 for both domains - solid mechanics and reinforced concrete structures - as recommended by Linacre (Linacre, 2012). Those values are shown in Table 3 for both control group and treatment group.

Table 3 - INFIT and OUTFIT statistics for control group and treatment group.

\begin{tabular}{lllllc}
\hline \multirow{2}{*}{ Group } & DOMAIN & \multirow{2}{*}{ INFIT } & \multirow{2}{*}{ OUTFIT } & \multicolumn{2}{c}{ RMSE } \\
\cline { 5 - 6 } Control & Solid mechanics & 0.98 & 0.92 & 0.21 & 0.20 \\
\cline { 2 - 6 } & $\begin{array}{l}\text { Reinforced concrete } \\
\text { structures }\end{array}$ & 0.99 & 1.08 & 0.59 & 0.59 \\
\hline \multirow{3}{*}{ Treatment } & Solid mechanics & 0.99 & 0.95 & 0.20 & 0.20 \\
\cline { 2 - 6 } & $\begin{array}{l}\text { Reinforced concrete } \\
\text { structures }\end{array}$ & 1.00 & 0.81 & 0.45 & 0.44 \\
\hline
\end{tabular}

Source: the authors.

Table 3 presents another statistics to fit data model: it is called RMSE. RMSE is the root-mean-square-error, a statistically more exact average for standard errors. Results for RMSE are composed of two parts: Model RMSE and Real RMSE. As the data fits better the model data, these values become close; in other words, for completed, reasonable-targeted tests these numbers are usually very close; but for incomplete short tests, they are noticeably different (Linacre, email, 22/02/2010). 
The RMSE statistics (Real and Model) are really closed, as shown in Table 3. It is possible to conclude that data was well fitted to the Rasch model. Therefore, those measurements generated data which were the input data to SPSS (2015) software to get the longitudinal model to construct the trajectories of change for the students of the reinforced concrete design course. The general equation MedCONC shown below is the outcome:

$$
\begin{aligned}
\text { MedCONC } & =\beta_{0 i}+\beta_{1 i} * \text { tempo }_{i j}+\rho_{1} * \text { idadeN }+\rho_{2} * \text { genero } \\
& +\cdots+\rho_{10} * \text { tempTRAB } 2
\end{aligned}
$$

Table 4 shows all predictor significance level values obtained with the initial SPSS (2015) model for both groups. The predictors were considered as significant if they had values lower than 0.05 or close to it (significant level $p<0.05$ ). They were combined in order to obtain the equation which better represents the trajectory for change.

Table 4 - Hierarchical model predictors variables.

\begin{tabular}{lc|c}
\hline \multirow{2}{*}{ Predictors } & \multicolumn{2}{c}{ Reliable range 95\% $(\mathbf{p}<\mathbf{0 , 0 5})$} \\
\cline { 2 - 3 } Intercept & Control group & Treatment group \\
\hline Time & 0.000 & 0.000 \\
\hline MechanicNLogit & 0.000 & 0.000 \\
\hline AgeN & 0.011 & 0.000 \\
\hline GenderN & 0.822 & 0.635 \\
\hline highSchoolLOC & 0.565 & 0.043 \\
\hline highSchoolOWN & 0.157 & 0.724 \\
\hline meanGSPN & 0.566 & 0.505 \\
\hline meanGPStrWeighN & 0.233 & 0.307 \\
\hline ScorePTN & 0.801 & 0.401 \\
\hline workedSTRUCT & 0.001 & 0.761 \\
\hline timeWORK & 0.452 & 0.082 \\
\hline Accessed & 0.936 & 0.079 \\
\hline
\end{tabular}

Source: the authors.

Despite the same procedure employed to construct the equation for both groups, the predictors used to adjust the model were not the same. Table 5 present the adjusted models for both control and treatment groups, while Table 6 shows the main statistics of fitted, 2LOG LIKELIHOOD (-2LL). -2LL is a statistical parameter similar to the least squares value used in regression analysis. If the independent variables have a relationship to the dependent variable, the ability to predict the dependent variable accurately will be improved, and the log likelihood measurement will decrease, indicating that the total amount of unexplained data is minimal. Significant positives and statistical differences $\left(\chi^{2}\right)$ between subsequent -2LL models direct the adjusted model (Field, 2009). According to -2LL values in Table 6 , it is possible to verify that there was a significant statistical decrease between subsequent constructed models. 

below:

The best model adjusted to the control group data is represented by the Equation 8

$$
\begin{gathered}
\text { MedCONC }_{i j}=-2,696-1,437 * \text { tempo }_{i j}+0,478 * \text { MecanicaNLogit }_{i j} \\
+0,500 * \operatorname{notaTPN}_{i}
\end{gathered}
$$

And the best model adjusted to the treatment group data is represented by the Equation 9:

$$
\begin{gathered}
\text { MedCONC }_{i j}=-3,642+1,010 * \text { tempo }_{i j}+0,423 * \text { MecanicaNLogit }_{i j} \\
+0,332 * \text { trabalhouESTRUT }_{i}+0,315 * \text { usou }_{i j} * \text { tempo }_{i j}
\end{gathered}
$$

\begin{tabular}{|c|c|c|}
\hline Sample & Mc & \\
\hline \multirow{3}{*}{$\begin{array}{l}\text { Control } \\
\text { Group }\end{array}$} & A & $\operatorname{MedCONC}_{i j}=-2.008-1.366^{*}$ time $_{i j}$ \\
\hline & B & MedCONC $_{i j}=-2.505-1.351 *$ time $_{i j}+0.586 *^{\text {scorePTN }_{i}}$ \\
\hline & $\mathrm{C}$ & $\begin{array}{l}\text { MedCONC }_{i j}=-2.696-1.437 * \text { time }_{i j}+0.500 * \text { scorePTN }_{i}+ \\
0.478 * \text { MechanicNLogit } \\
\text { ij }\end{array}$ \\
\hline \multirow{4}{*}{$\begin{array}{l}\text { Treatment } \\
\text { Group }\end{array}$} & A & $\operatorname{MedCONC}_{i j}=-3.368+1.230 * t_{i m e} e_{i j}$ \\
\hline & B & MedCONC $_{i j}=-3.588+1.176 *$ time $_{i j}+0.434 *$ MechanicNLogit $t_{i j}$ \\
\hline & $\mathrm{C}$ & $\begin{array}{l}\text { MedCONC }_{i j}=-3.647+1.186 * \text { time }_{i j}+0.387 * \text { MechanicNLogit }_{i j}+ \\
0.307 * \text { workedSTRUT }_{i}\end{array}$ \\
\hline & $\mathrm{D}$ & $\begin{array}{l}\text { MedCONC }_{i j}=-3.642+1.010 * \text { time }_{i j}+0.423 * \text { MechanicNLogit }_{i j}+ \\
0.332 * \text { workedSTRUT }_{i}+0.315 * \text { accessed }_{i j} * \text { time }_{i j}\end{array}$ \\
\hline
\end{tabular}

Table 5 - Adjusted structure model for CG and TG groups.

Source: the authors.

Table 6 - (-2LL) statistical adjustment results.

\begin{tabular}{l|c|c}
\hline Sample & Model & -2log Likelihood \\
\hline \multirow{3}{*}{$\begin{array}{l}\text { Control } \\
\text { Group }\end{array}$} & $\mathrm{A}$ & $745.654^{* *}$ \\
\cline { 2 - 3 } & $\mathrm{B}$ & $732.835^{* *}$ \\
\hline & $\mathrm{C}$ & $723.729^{* *}$ \\
\cline { 2 - 3 } Treatment & $\mathrm{A}$ & $654.624^{* *}$ \\
\cline { 2 - 3 } Group & $\mathrm{B}$ & $643.005^{* *}$ \\
\cline { 2 - 3 } & $\mathrm{C}$ & $610.419^{* *}$ \\
\hline & $\mathrm{D}$ & $605.284^{* *}$ \\
\hline
\end{tabular}

Source: the authors. 
Each parameter considered in two equations above are significant at level $p<0,01$. All students in both groups started the course with negative value for the intercept, i.e., initial knowledge. This means lower probability of success on easy and difficult items (questions) by the students. Performance change rate of control group in the reinforced concrete design course over the time is negative, whereas it is positive for the treatment group, -1.437 and 1.010, respectively. MechanicNLogit predictor values for both groups are very close and have a positive influence in the students' performance as would be expected.

The control group scorePTN predictor influences positively on student performance, whereas this did not happen for the treatment group, as shown in Table 4. On the other hand, the treatment group predictor variable workedSTRUT influenced positively on intercept rate and it was not a significant predictor variable for the control group. The main predictor, accessed had a positive influence on students' performance in the reinforced concrete design course. The graphic of Figure 4 presents the mean trajectory of students' performance in the control group and the graphic of Figure 5 presents mean trajectory of students' performance in the treatment group and shows the workedSTRUT and accessed positively influence this performance.

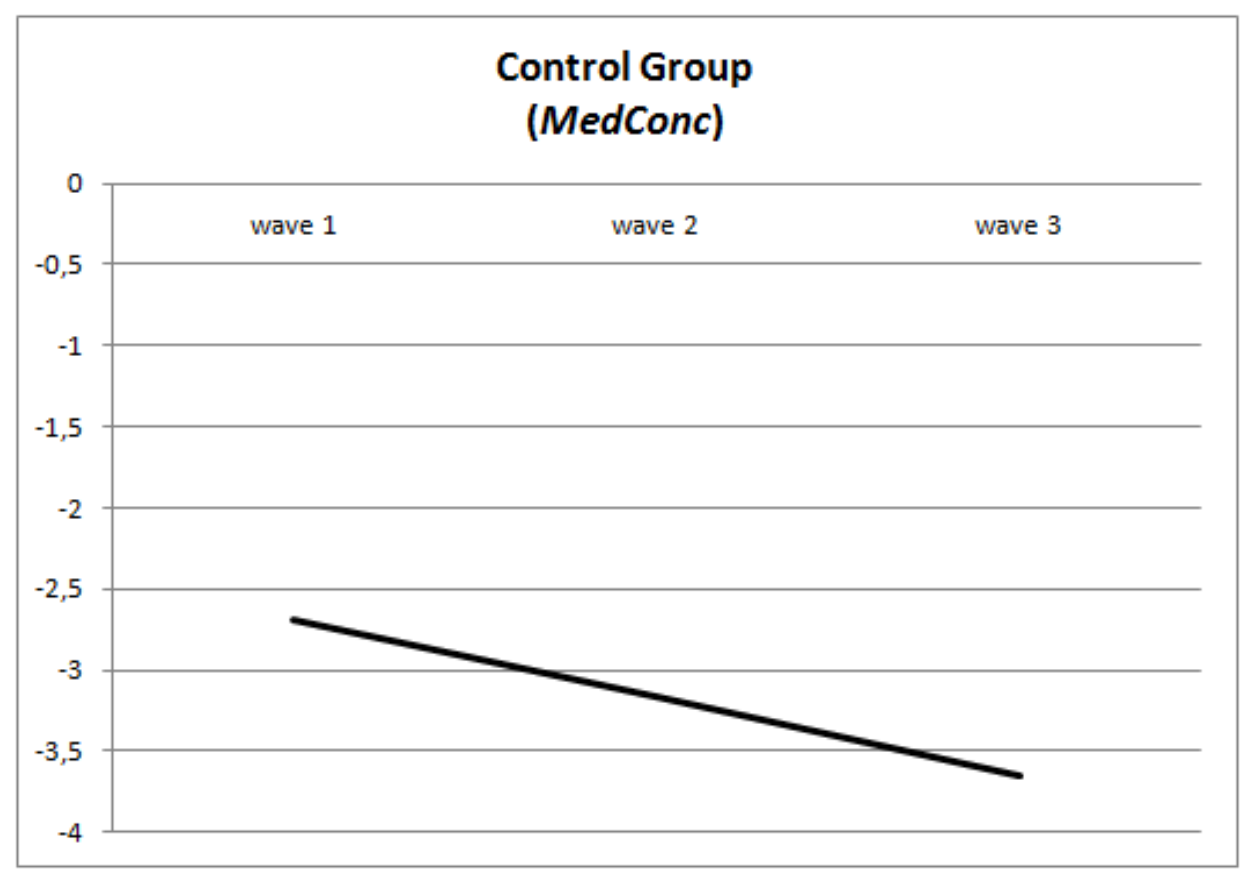

Figure 4 - Performance mean trajectory of control group.

Source: the authors. 


\section{Treatment Group \\ (MedConc)}

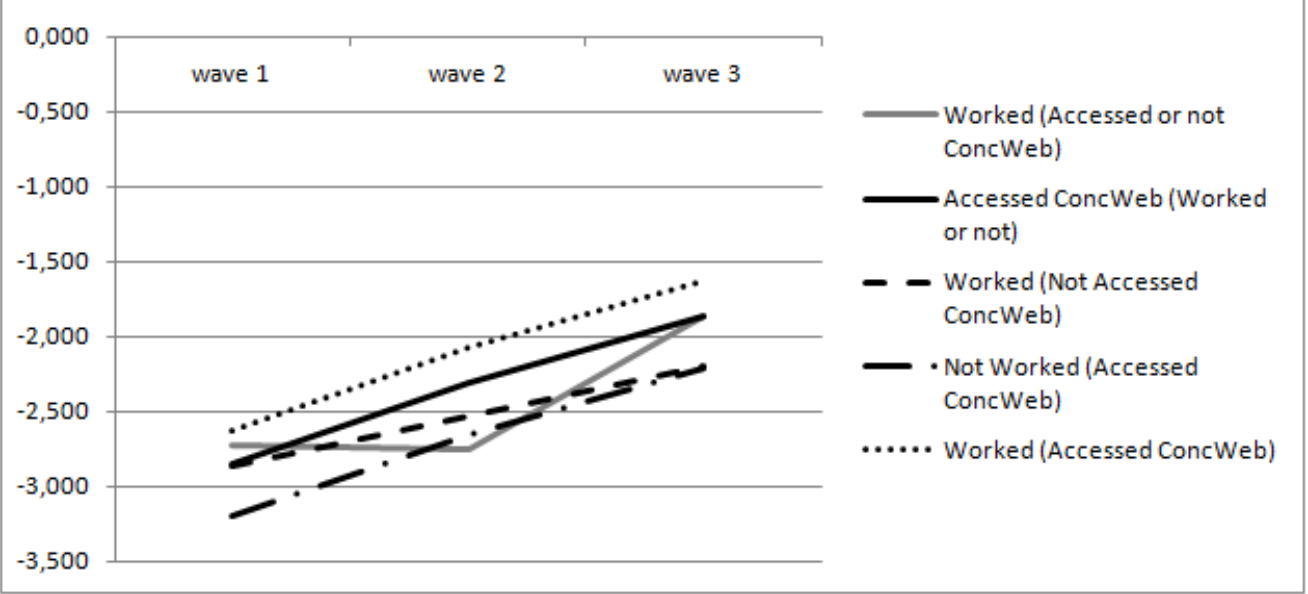

Figure 5 - Performance mean trajectory of treatment group.

Source: the authors.

Table 7 shows variance values $(\Delta)$ between initial and final students' performance measurements, considering all possible relations between predictors workedSTRUT and accessed.

Table 7: Influence of workedSTRUT and accessed on reinforced concrete student performance

\begin{tabular}{lllll}
\hline trabalhouESTRUT & accessed & Initial Value & Final Value & $\Delta$ \\
\hline 1 & $1 / 0$ & -2.720 & -1.857 & 0.863 \\
\hline $1 / 0$ & 1 & -2.852 & -1.864 & 0.988 \\
\hline 1 & 0 & -2.867 & -2.194 & 0.673 \\
\hline 0 & 1 & -3.200 & -2.210 & 0.990 \\
\hline 1 & 1 & -2.621 & -1.632 & 0.989 \\
\hline
\end{tabular}

Source: the authors.

As shown in Table 7, when the value of predictor variable accessed (indicating whether student accessed or not ConWeb) is 1 , a significant change occurs in students' performance. These results show a positive influence of ConcWeb in the student learning process, since the accessed predictor is an important factor in the equation for the longitudinal study of the group which used the environment. 


\section{CONCLUSIONS}

Can ConcWeb positively influence students' performance of reinforced concrete design course?

There are strong evidences that ConcWeb positively influences students' performance in reinforced concrete design course. The best hierarchical longitudinal model to represent the students' trajectories of change emphasizes that working, as a part-time trainee, in the structural area and use the ConcWeb as aid tool for learning considered together were important to improve students' performance. In addition, the synergy between both of them was observed. When the predictor accesses is included in the model equation (Model D versus Model $\mathrm{C}$ in table 5), the statistical adjustment result is better, demonstrating the influence of ConcWeb as a support learning tool.

The student group who accessed ConcWeb was also invited to answer some questions about the environment. For each question a student could select one of five-level Likert item. They also could write their opinion about the environment. About $87 \%$ of students consider ConcWeb design and detailing tools for reinforced concrete elements relevant. The use of the environment influenced the pupils' knowledge of the subject in $62 \%$ of the cases. The large majority of the students approved the visual resources and organization of the environment and would use ConcWeb again. They also suggest that ConcWeb should be employed as early as possible during the reinforced concrete design course.

Thus, the environment designed and developed in this research proved to be an important tool to support the teaching and learning process for reinforced concrete design. It was concluded that ConcWeb helps not only the students but also lectures as follows:

- It facilitates description of contents as it employs both visualization and audio;

- It acts as an extension of the classroom, since students are free to access the environment anytime and anywhere;

- It ensures students good quality of information since all the available contents are analyzed and validated by professors;

- It saves time searching topics about reinforced concrete design because ConcWeb serves as a repository for the subject.

In addition, the results presented herein showed empirical evidence that the knowledge of Solid Mechanics is essential for understanding reinforced concrete design.

The basic idea behind this proposed approach is not to discard the traditional classroom teaching method, but to create complementary alternatives, which aid lectures to enhance the student's performance. 


\section{REFERENCES}

ABED - BRAZILIAN ASSOCIATION FOR DISTANCE LEARNING. 2015. ABED. Available at: 〈http://goo.gl/vkvCz $>$. Accessed in: 01 June 2015.

ARIFFIN, Siti Rahayah; ASARI, Suriana Mohd; MOHAMED, Shafiza; SHAHAR, Shah Nazim; ISHAK, Noriah Mohd; DIN, Rosseni; AHMAD, Abdul Ghafur; YAMAT, Hamidah; MAJID, Rosadah; YASIN, Siti Fatimah Mohd.. Validity of UKM1 Intelligence Test using rasch analysis. Procedia Social and Behavioral Sciences, v. 07, p. 205 - 209. 2010. Available at: 〈http://goo.gl/9cHBhU>. Accessed in: 01 June 2015. ISSN 1877-0428.

ARSAD, Norhana; KAMAL, Noorfazila; AYOB, Afida; SARBANI, Nizaroyani; TSUEY, Chong Sheau; MISRAN, Norbahiah; HUSAIN, Hafizah. Rasch model analysis on the effectiveness of early evaluation questions as a benchmark for new students ability.

International Education Studies, Toronto, Canadá, v. 06, n. 06. 2013. Available at: <http://goo.gl/IJqI36>. Accessed in: 06 July 2015. ISSN 1913-9039.

BENNETT, Susan .J.; MATON, Karl A. Beyond the 'digital natives' debate: towards a more nuanced understanding of students' technology experiences. Journal of Computer Assisted Learning, Heerlen, Netherlands, v. 26, p. 321-331. Available in: < http://goo.gl/WGiaXN>. Accessed in: 06 July 2015. ISSN 1365-2729.

COURSERA. 2014. COURSERA. Available at: 〈https://goo.gl/NUiFd >. Accessed in: 01 June 2015.

DIGGLE, Peter; HEAGERTY, Patrick; LIANG, Kung-Yee; ZEGER, Scott. Analysis of longitudinal data. Oxford: Oxford University Press, 2002.

DROUIN, Michelle; HORNER, Sherri L.; SONDERGELD, Toni A. Alphabet knowledge in preschool: a rasch model analysis. Early Childhood Research Quarterly, Elsevier, United States, v. 27, n. 03, p. 543-554. 2012. Available at: 〈http://goo.gl/LDOr6J $\rangle$. Accessed in: 01 June 2015. ISSN 0885-2006.

DRYSDALE, S. Jeffery; GRAHAM, Charles R., SPRING, Kristian J.; HALVERSON, Lisa R. An analysis of research trends in dissertations and theses studying blended learning. Internet and Higher Education, Elsevier, United States, v. 17, p. 90-100. April 2013. Available at: < http://goo.gl/oB6aqP>. Accessed in: 06 July 2015. ISSN 1096-7516.

EDX. Available at: 〈https://goo.gl/42GGl>. Accessed in: 01 June 2015.

FEDERAL UNIVERSITY OF MINAS GERAIS. 2015. UFMG. Available at: <http://goo.gl/XxLNUL>. . Accessed in: 01 June 2015.

FIELD, Andy. Discovering statistics using SPSS. 3. ed. London: SAGE Publications. 2009. 
GOOGLE ANALYTICS. GOOGLE. Available at: 〈http://goo.gl/ktRQ>. Accessed in: 01 June 2015.

GÜZER, Bayram; CANER, Hamit. The past, present and future of blended learning: an in depth analysis of literature. Procedia - Social and Behavioral Sciences, Elsevier, United States, v. 116, n. 21, p. 4596-4603. February 2014. Available at: 〈http://goo.g1/ss4sSm>. Accessed in: 06 July 2015. ISSN 1877-0428.

JOOMLA! JOOMLA! Available at: 〈https://goo.gl/yu545I > Accessed in: 01 June 2015.

LAWTON, Daryl; VYE, Nancy; BRANSFORD, John; SANDERS, Elizabeth; RICHEY, Michael; FRENCH, David; STEPHENS, Rick. Online learning based on essential concepts and formative assessment. Journal of Engineering Education, United States, v. 101, n. 02, p. 244-287. April 2012. Available at: 〈http://goo.gl/7DpZAK〉. Accessed in: 06 July 2015. ISSN 2168-9830.

LCC - UFMG SCIENCE COMPUTATIONAL LABORATORY. LCC. Available at: <http://goo.gl/hmvZKu >. Accessed in: 01 June 2015.

LINACRE, Mike. Winsteps Tutorial - 2012. Available at: 〈http://goo.gl/rTTGmW〉. Accessed in: 01 June 2015.

MEAD, Ronald. A rasch primer: the measurement theory of Georg Rasch. Data Recognition Corporation, 2008.

MIT - MASSACHUSETTS INSTITUTE OF TECHNOLOGY: Open Course Ware. 2015. MIT. Available at: 〈http://goo.gl/BXpY〉. Accessed in: 01 June 2015.

MOLYNEAUX, Tom; SETUNGE, Sujeeva; GRAVINA, Rebecca; XIE, Mike. An evaluation of the learning of structural engineering concepts during the first two years of a project-based engineering degree. European Journal of Engineering Education, v. 32, n. 01, p. 01-08. March 2007. Available at: < http://goo.gl/CVqY5g>. Accessed in: 06 July 2015. ISSN 14695898.

MPLUS. 2015. MPLUS. Available at: 〈http://goo.gl/GeCE4>. Accessed in: 01 June 2015.

MULTIPLUS. 2015. MULTIPLUS. Available at: 〈http://goo.gl/OPKaA $>$. Accessed in: 01 June 2015.

MUTHÉN, Linda K.; MUTHÉN, Bengt O. MPlus - User Guide. 5. ed. Los Angeles, USA: Murthén \& Murthén. 2007. Available at: 〈 https://goo.g1/I8iSzE〉. Accessed in: 26 July 2015.

NIELSEN, Jakob; LORANGER, Hoa. Projetando websites com usabilidade. Rio de Janeiro: Elsevier, 2007. 432 p. 
ONLINE LEARNING CONSORTIUM. 2015. ONLINE LEARNING CONSORTIUM. Available at: <http://goo.gl/JGRjFq>. Accessed in: 01 June 2015.

PEUGH, James L. A practical guide to multilevel modeling. Journal of School Psychology, Elsevier, United States, v. 48, n. 01, p. 85-112. 2010. Available at: $\langle\underline{\text { http://goo.gl/u } 4 X c r X}\rangle$. Accessed in: 06 July 2015. ISSN 0022-4405.

PONTYDYSGU. 2015. PONTYDYSGU. Available at: 〈http://goo.gl/YRPdL〉. Accessed in: 01 June 2015.

PRESSMAN, Roger. Software engineering: a practitioner's approach. 5. ed. New York, USA: McGraw-Hill. 2007.

PONTIFICAL CATHOLIC UNIVERSITY OF RIO DE JANEIRO. 2015. PUC-Rio. Available at: < http://goo.gl/GRnSnH $>$. Accessed in: 01 June 2015.

SAP2000. 2015. SAP2000. Available at 〈http://goo.gl/S2Qkpt $\rangle$. Accessed in: 01 June 2015.

SHEPHERDSON, Emma. Teaching concepts utilizing active learning computer environments. 2001. PhD Dissertation (Civil Engineering) - Massachusetts Institute of Technology, Massachusetts, USA, 2001. Available at: < http://goo.gl/9hTD1p >. Accessed in: 26 July 2015.

SHNEIDERMAN, Ben; PLAISANT, Catherine. Design the user interface: strategies for effective human-computer interaction. 4. ed. New York: Pearson Education, 2005. 652 p.

SINGER, Judith D; WILLET, John B. Applied longitudinal data analysis. New York: Oxford University Press, Inc. 2003.

SPSS. 2015. SPSS. Available at: < http://goo.g1/JZzUEK>. Accessed in: 01 June 2015.

SWEDISH NATIONAL AGENCY FOR HIGHER EDUCATION. E-learning quality Aspects and criteria for evaluation of e-learning in higher education. Stockholm: Swedish National Agency for Higher Education. 2008.

TAKAHASHI, Tadao (Org.). Sociedade da Informação no Brasil: Livro verde. Brasília: Ministério da Ciência e Tecnologia, 2000. 195 p.

TQS. 2015. TQS. Available at: 〈 http://goo.g1/L4aP31>. Accessed in: 01 June 2015.

VEDUCA. 2015. VEDUCA. Available at: 〈http://goo.gl/hdPSr $>$. Accessed in: 01 June 2015. WINSTEPS. 2015. WINSTEPS. Available at: 〈http://goo.gl/WefaoZ〉 . Accessed in: 01 June 2015. 
WRIGHT, Benjamin D.; MOK, Magdalena M.C. An overview of the family of rasch measurement models. Maple Grove, MN: JAM Press. 2004. Available at:

<http://goo.gl/ICHHo3 $>$. Accessed in: 01 June 2015.

WU, Margaret; ADAMS, Ray. Applying the rasch model to psycho-social measurement: a practical approach. educational measurement solutions. Melbourne, 2007. 87 p. Available at: < http://goo.gl/XZ3Z5d >. Accessed in: 26 July 2015.

\section{ACKNOWLEDGMENTS}

The authors would like to thank PROGRAD / UFMG (https://goo.gl/NYwvYJ) for the financial aid.

\section{Como citar este documento:}

MELLO, Gláucia Nolasco de Almeida; MAIA, Elizabeth Vieira; CALIXTO, José Márcio Fonseca. CONCWEB: hybrid learning tool for reinforced concrete design. ETD - Educação Temática Digital, Campinas, SP, v. 18, n. 1, p. 156-177, abr. 2016. ISSN 1676-2592. Disponível em: <http://periodicos.sbu.unicamp.br/ojs/index.php/etd/article/view/8638248>. Acesso em: 05 abr. 2016. doi: 〈http://dx.doi.org/10.20396/etd.v18i1.8638248>. 